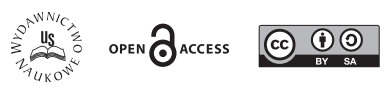

„Analiza i Egzystencja” 56 (2021), 5-23

ISSN (print): 1734-9923

ISSN (online): 2300-7621

DOI: $10.18276 /$ aie.2021.56-01

ARTYKUŁY

MAGDALENA ŻARDECKA *

ORCID: 0000-0003-3581-6424

\title{
DIFFICULT BIRTH OF THE AGENT. MEMORY OF THE BODY, IDENTITY AND SOCIAL COMPETENCE
}

Keywords: body memory, training, drill, time, subjectivity

Słowa kluczowe: pamięć ciała, ćwiczenie, musztra, podmiotowość

Society forms individuals, submitting them to continuous processes of training and disciplining. Individuals, on the other hand, turn out to be susceptive of receiving such external conditioning, able to memorize lessons

* Magdalena Żardecka - specializes in contemporary philosophy, social philosophy, philosophy of politics and philosophy of culture. Author of the books: Wspólnota i ironia. Richard Rorty i jego wizja spoleczeństwa liberalnego („Commonwealth and irony. Richard Rorty's Vision of Liberal Society"; Lublin: Wydawnictwo KUL, 2003), Rozum i obywatel. Idea rozumu publicznego oraz koncepcja jednostki we współczesnej filozofii polityki (,Reason and Citizenship. The Idea of Public Reason and Conception of the Individual in Contemporary Philosophy of Politics"; Rzeszów: Wydawnictwo Uniwersytetu Rzeszowskiego, 2007), Pamięć i zapomnienie. Filozoficzny dyskurs o sile i słabości pamięci indywidualnej i zbiorowej (,Memory and Oblivion. A Philosophical Discourse on Strength and Weakness of Individual and Collective Memory"; Rzeszów: Wydawnictwo Uniwersytetu Rzeszowskiego, 2020).

Address for correspondence: Uniwersytet Rzeszowski, Instytut Filozofii, Al. Rejtana 16C, 35-959 Rzeszów, Poland. E-mail: magda.zardecka@gmail.com. 
given to them, and to modify under their influence not only their behavior, but also their ways of thinking and feeling. Humans interiorize social pressures, to such an extent that they are being internalized and become integral part of their identity. Interiorization of this kind is an important form of human memory.

Considered from this angle, human memory gets desubjectified and becomes mainly a social issue, a product of external pressure, training and enforced socialization. If memory - as a topic in itself - is an important figure of the whole process of cognition, of the way human "subjects" deal with "the world", then, viewed by this particular lens, it shares the destiny of modern subject as such. As the history of cartesianism and phenomenology shows, introspective, first-person subjective insight in one's reflexively considered and reconsidered contents of private consciousness becomes more and more the individual's prereflexive, embodied interaction with the world, conditioned and shaped by environment and its onto- and phylogenetic history. ${ }^{1}$ In more memetical as mnemological terms, we - if there still is such a thing as "we" and "I" - are not so much (although as well) fruits of continuous commemoration, results of constant reiteration of memory, based on conscious and conspicuous reminiscence, on remembering re-membered, based on reminding, reminiscing and aware recognizing (cf. Casey), as rather-more fundamentally - embodied agents, immersed in the world that un- or preconsciously shapes us through our bodies. It is the body that projects and creates our time, makes our time happen; "My body takes possession of time, creates the existence of the past and of the future for the sake of the present, [...], it makes time instead of merely being subjected to it" (Merleau-Ponty, 2001, p. 277; cf. Pokropski, 2013, p. 44). Thus we are not so much subjects, i.e., supposed lords of our memories, identity

1 Admittedly, Husserl implicitly disclaims any affiliation to introspectivism, highlighting the distinction between phenomenology and the psychological method, consisting in empirical analysis of conscious contents (Husserl, 1998, § 79; § 8; see Gallagher, Zahavi, 2008). Yet Husserl's relation to psychology (and hereby to the paradigm of psychological introspection) remains ambivalent (see Pokropski, 2013, p. 18). Reproaches on Husserl concerning the introspective character of his philosophy are still present in philosophical literature (see Pokropski,2013, p. 64 f. ; Dennett, 1991, p. 44; Miłkowski, 2003). It seems that we are still far away from the full discovery of the new access to subject's way to the world and to the „Sachen selbst”, outlined in Husserl's phenomenology. 
and destiny, as rather simply subject to them - subject to constant forming, shaping, modelling, and disciplining, exercised by our environment.

It is a common and a well known misery of philosophy to be constantly obliged to return to the question and issue of the subject - and yet this question returns, for we are unable to speak about our identity, memory and our ability to cope with the world otherwise. But how to pose it differently, how to reformulate it? How to avoid the very notion of "subject", the point of departure of modern philosophy, that so often gets us into trouble? To escape the trap of "subjectivity" provisionally, still having in mind the validity and utmost significance of the issue of the subject, we will not refer to the important motives of mnemonical reflection present in philosophical considerations of Edmund Husserl and Henri Bergson, discussed extensively in my book on memory and oblivion (see Żardecka, 2020).

The point of reflections proposed in this paper is to consider and ponder various ways of analyzing the disciplining, embodied practices shaping our memory, in order to try to approximate to an answer to this very question. And if we succeed, even partially and without a clear formulation of the result, it will be a considerable gain.

Let us then ask - how could we (let us say: "we as we") enjoy relative independence, rather contributing to the final result of coercive practices of socialization than merely opposing them? Such an art - rare and common alike, as it is - must be a form of acrobatic ascesis, interiorizing social pressures, while playing with them at the same time. It is in this sense that Peter Sloterdijk formulates his programme of acrobatic ethics, trying to anchor and to settle us in the "planet of practicing" - keeping, as he says, a "happy distance from the chimeras of "philosophical anthropology"." We should thus assume that we live in the "enclosure of disciplines", conceived as practices of disciplining - whether we call them "institutions", paternal "symbolic order" (Lacan) or "habitus" (Bourdieu) (Sloterdijk, 2013, p. 109-110). But at the same time we should not forget that our submission to this order, institutions or habitus has an intrinsically reflexive characterparadoxically, not only our body (with all its adjacent conditions, liabilities and determinisms), but also we ourselves "make time instead of merely being subjected to it." As Sloterdijk poignantly expresses this paradox, the clue of it is "the autopoietic constitution of the essential human facts. Being human means existing in an operatively curved space in which actions return to affect the actor, works the worker, communications the communicator, 
thoughts the thinker and feelings the feeler. All these forms of reaction [...] have an ascetic, that is to say, a practicing character - although [...] they largely belong to the undeclared and unnoticed asceticism or the occulted training routines" (Sloterdijk, 2013, p. 110).

Let us then try to follow this particular feedback character of embodied memory and identity, with the above outlined paradox in mind.

Institutions, embodied practices and difficult birth of identity Maurice Halbwachs, Norbert Elias, Marcel Mauss

Memory conceived as a faculty of the individual mind constitutes an important topic of philosophical reflection since antiquity to this day (Plato, Augustine, Bergson). On the other hand, the social aspect of this process remained for a long time beyond the range of philosophical reflection. Scarce, although very significant remarks concerning memory of the body are to be found in Nietzsche's writings. In the seminal roman of Marcel Proust there are many motives referring to the bound between the body and senses which, under the influence of accidental agitation (position of the body, the taste of the cake) set in motion cascades of spontaneous reminiscences (see Żardecka, 2020, p. 168). Henri Bergson, a philosopher who inspired Proust, devoted many of his considerations to the issue of embodied forms of memory (motor memory, habitual memory). Yet his disciple, Maurice Halbwachs, who introduced the notion of the social frameworks of memory, distanced himself to this particular aspect of Bergson's analyses, reducing his field of interest only to the graspable content of our conscious life. As he remarked, although behind every image of memory there is always a motor aspect, we would complicate unnecessarily the issue, obfuscating the whole subject matter, speaking about the body instead of limiting ourselves to analyzing states of consciousness (Halbwachs, 1925, pp. 139-140).

The first author to focus on social practices of teaching and disciplining the body, who undertook the description of the process of shaping individuals and increasing control over their drives and affects, as well as of enforcing certain attitudes and behaviors, was Norbert Elias, who wrote in the 1930s 
(Elias, 1939; 1969). ${ }^{2}$ Elias noticed the phenomenon of congruity between the social structure and its corresponding mental and behavioral type represented by individuals, which he referred to as habitus. He showed how external coercion (Fremdzwang), in the form of fear of punishment and hope of reward, transforms in the process of civilization into inner coercion (Selbstzwang), effectively assuring observance of social norms. In effect, our own self rewards us for accepted and proper behavior, giving us satisfaction, aesthetic pleasure, moral complacency and good mood, or punishes us for improper behavior, inducing in us the sense of annoyance, shame or guilt. Socialization does not consist in instilling rigid schemes of behavior and action, but in drilling us in interactive ways of adapting to the environment. Individuals always enjoy a certain degree and are allowed certain field of autonomy, liberty of decision and potential innovativeness, allowing them to express their feelings and to shape individually relations with others.

Culture is not a stable set of immutable elements. Customs that pass for immemorial and primeval unravel their mutability on closer analysis. Ways of behavior proper to participants of a given interaction turn out to depend on such factors as the social status of actors, dependences existing between them, time, place and many other circumstances. To individuals engaging in interaction, bound to one another by certain relationships (of kinship, fellowship, professional reporting lines) are ascribed certain capacities of power, defined within this particular set of cultural interdependences, that usually are not distributed symmetrically, and certain possibilities of action. Such settings Elias called figurations (Figurationen). Their specific feature consists in appearing and persisting in movement. Education and all forms of training reach deeply into the human behavioral structures, modelling reactions and functioning of the body and marking all affects and instincts. The more civilized is a given society, the greater pression it exerts on the bodies of individuals and the greater control it performs over their drives and emotions, without, however, depriving them of their agency and of a certain, greater or lesser, amount of liberty, what makes the society retain its remarkable flexibility, in spite of all its rigidness (Elias, 2010).

2 The first, German edition of Elias's oeuvre, published in Switzerland in 1939, remained almost entirely unnoticed for historical reasons, due to the Jewish descent of the author. It is only its second, English edition, that brought him well deserved recognition. 
A similar account of the same issue we find in writings of the French anthropologist Marcel Mauss, who underlined and described social dependencies of human bodily existence. All apparently natural ways of behavior, such as a way of sitting, sleeping, walking or breathing, express group adherence and social position of members. Mauss was the first to introduce the notion of habitus, defined by him as a technique and an accomplishment of collective and individual practical reason, reproducing itself in the process of imitation (Mauss, 1950, pp. 365-390). This notion of habitus shall be later undertaken and developed by Pierre Bourdieu (Bourdieu, 1990, p. 52 f., 98 f.).

Habits and habitus - our identity in social force fields.

Michel Foucault, Pierre Bourdieu

Basing on extensive and detailed historical inquiries, Michel Foucault comes to a conclusion that human bodies always have been systematically disciplined, subjugated, stigmatized and ruined by factors of power; they constitute a major arena, in which the struggle of powerful forces took and still takes place. Foucault analyzed ways in which different social institutions (school, army, prison) effectuate painful treatment of human bodies, which then become colonies of interiorized order (Foucault, 1995). Not only our past, but also the history of our ancestors inscribes itself in our nervous system, in our muscles, intestines and disposure (Foucault, 1984). The body appears "in faulty respiration, in improper diets, in the debilitated and prostrate bodies of those whose ancestors committed errors. Fathers have only to mistake effects for causes, believe in the reality of an 'afterlife', or maintain the value of eternal truths, and the bodies of their children will suffer. [...] The body maintains, in life as in death, through its strength or weakness, the sanction of every truth and error, as it sustains, in an inverse manner, the origin - descent." (Foucault, 1984, p. 82) The body is the inscribed surface of events, the locus of a dissociated self, creating the illusion of substantial unity. Individual bodies have always been subject to painful cultural treatment and reworking, and the agents of power were entitled to discipline and to take lives. In modernity to the foregoing prerogatives came still another: the life of entire societies has become an outcome of applying political strategies. Not only individual bodies, but the 
huge collective body (society, nation) has become the subject of formatting performed by power and in aggregate inscribed this lesson in its memory. Politics has changed into biopolitics, power into biopower, managing the life and death of whole human collectivities (racism, national socialism, disciplining reproduction, planned extermination - see Foucault, 1990, 1997. The reflection on biopolitics is continued by Giorgio Agamben, Antonio Negri, Michael Hardt; see Lemke, 2011).

Another keen contemporary explorer of human customs and habits is the French philosopher and sociologist Pierre Bourdieu. He believes that the fundament of social unity, durability and stability, the foundation of all understanding between men is primary accord, commonsensical consensus concerning the meaning of the world. Common sense is communal (national or civil in character) and is a result of habits (customs, automatisms) instilled in all members of a given group (citizens). Bourdieu (similarly to Pascal, Foucault and Connerton) claims that symbolic power of authority influences directly the body (training, taming) that assimilates relationships of domination (it is the clue of the magic of power). Dependency manifests itself in posture, in voice, in facial expressions; it is not a thought, a choice, a decision, but a silent practical conviction that could emerge only as a result of a long training, molding automatisms in bodies (dispositions) and minds (opinions) of subordinated individuals. It is possible only through parallel action of many different social institutions, working on instilling in all members of society certain determined principles of thinking and rules of conduct (cognitive, social and moral conformism). Thus emerges prereflexive consensus about the meaning and sense of the world. Thanks to habits the received order of things appears to us as necessary, natural and self-evident (the miracle of evidence, the miracle of validity, the miracle of assent).

Bourdieu describes culture as cooperation of different fields; each of them has its own constitution (foundation act, nomos) and each is founded on the unshaken fundament of tautology: law is law, business is business, art is art. Having recognized the point of view proper to a given field, we cannot look on it from the outside (Bourdieu, 1990, pp. 66-71). Nomos has no antithesis; it is a thesis that cannot be denied, for it has never been explicitly expressed; it is a principle that constitutes the field. There are various fields, governed by various laws, and powers and authorities acting in them usually do not take notice of one another. Varied are stakes and 
profits proposed by each of the fields. Such valours as wealth, intelligence, physical fitness, bureaucratic pedantry etc. do not match with one another; a businesman, a scientist, an artist, a sportsman and a functionary, entirely engaged in their work, do not even try to compete with one another. Each field, as a different form of life, is an operating space of a different cultural game, and each game opens access to other aspects of reality. Every particular point of view creates its object and suggests principles of understanding and explaining itself (Bachelard). Cognitive structures are not, according to Bourdieu, forms of consciousness, but dispositions of the body, formed in a definite field through long-running exercises and repetitions (Bourdieu, 1998, p. 54).

Ensembles of abilities, skills and faculties (systems of durable dispositions) acquired through life in a given society, transferred by family, school, authorities, institutions calls Bourdieu habitus (Bourdieu, 1992, p. 115 f; cf. Bourdieu, 1990, p. 53). Habitus is practical sense, ability of sensing the game, ability to act and behave properly, not entirely conscious, inexpressible knowledge about what we should say and how we should react in various situations, art of anticipating of what is going to happen, prudence in action, impeccable style, a coherent system of values, an always accurate choice of persons, goods and practices (Bourdieu, 1998, pp. 8-9). Habitus organizes actions and ideas of men and makes them competent participants of a given game - lawyers, scientists, citizens. It is the way in which the past (of the whole society) is always present in us - as "embodied history", persisting in actual time (Bourdieu, 1990, p. 56). Habitus is a dimension of our practical sense (different from rational calculation and conscious application of norms), allowing us to promptly realize goals that would be only slowly and inefficiently followed by reason; it is the player's experience, subtle tact, intuition, discriminating taste, educated style; it is all the proper and correct ways of thinking and perceiving, unrestricted mobility, precision of actions. Habitus is the foundation of silent communication between actors (in spite of lack of any direct, explicit interaction between them), who are product of the same conditions and similar experiences. Thanks to habitus the practical world is a world of realized objectives (p. 55) and a world of forgotten history (p. 56). "The habitus - embodied history, internalized as a second nature and so forgotten as history - is the active presence of the whole past of which it is product. As such, it is what gives practices their relative autonomy with respect to external determinations of the immediate present. 
This autonomy is that of the past, enacted and acting, which, functioning as accumulated capital, produces history on the basis of history and so ensures the permanence in change that makes the individual agent a world within the world." (p. 56) As the immanent law (lex insita) habitus is equally the opposite of mechanical necessity as it is opposite of reflexive liberty, that is, of "a res without history."

Groups are created by spontaneously coordinated habitus. Their members confirm and legitimize their behavior and behavior of the group, making all insiders feel at home, even if they did not choose the habitus - this "unchosen principle of all choices" (p. 61). Ways of action and constructional schemes, applied by actors to the world, have been given to them from outside, as if they were constituted by an objective world. Thanks to their interiorization individual history meets with collective history (mechanisms and structures acting in social space and in individual mentalities coincide). Habitus endow all new experiences with adequate structure. As a product of history and society, they capacitate their actors for assimilation of history and participation in social life. We have to do here with a situation in which the body is in the social world and vice versa, the social world is in the body; history communicates with itself and regards itself in the process of self-reflection. This process is characterized by the effect of total and direct adjustment and accommodation. Miraculously adapted individuals go to meet the well-known, predictable world. They distinguish themselves by self-confidence, excellent mood and strong bonds with others. ${ }^{3}$ Among elements concurring to the formation of their habitus are impeccable manners, various abilities, a set of right answers to all important questions, unerring judgment, linguistic competences (clear, precise utterances). Automatization expels into the unconscious the source of these capacities, attitudes, actions and views; it expels into the unconscious tools of thinking and the history of learning and education. One of essential dimensions of habitus is "knowledge" about everything that should not be mentioned, that should be overlooked, about things that we should turn a blind eye to (self-deception, collective bad faith - Bourdieu 1998, p. 119). Reflection, with great effort,

3 Evidently in every society there are individuals contending with the problem of maladjustment. Their habitus are (for various reasons) unadapted and inadequate to fit to their time and circumstances. Dysfunctionality will be always the common fate of both parvenus and déclassés as well as of apparatchiks, whose adaptation is all too visible and rigid, and hence caricatural. 
is able to uncover some mechanisms and tools, but cannot liberate thinking and action from coercion.

The advantage of habitus is their capacity to allow groups to maintain cohesion and durability without putting on the individuals' shoulders the burden of making conscious decisions and choices, as well as of reaching for violence and engaging guards. We are all people of the past - the past is present in every action suggested by habitus and in every anticipation of the future, but we do not perceive it, for it constitutes our permanent equipment, situated at a deeper level than our consciousness is able to reach (a hidden and the most solid fundament of group integration). Everything changes, however, when the situation begins to differ from what we got used to (crisis, revolution), when every our move falls into the void or triggers negative reaction of our environment, and every prediction of the future turns out to be wrong. In spite of the fact that their dispositions have lost their utility and have become obsolete (they already belong to another cultural context), actors, tethered by their overwhelming power, abide by them, helpless towards the new reality and towards themselves, because they are not capable of change.

Bourdieu shows that the processing of the body begins in our earliest childhood. Under the cover of trivial charges, such as "Straighten up!", the child is imbued with all the cosmology, ethics, metaphysics and politics s/he is about to absorb. The most insignificant details, such as position of hands at meals, turn out to be closely connected with fundamental principles of a given culture. In the course of education spiritual values become flesh (a real miracle of transsubstantiation - Bourdieu, 1980, p. 1174; cf. Bourdieu, 1990, p. 69). The technique of the body, according to the logic of scheme transfer, is able in any time to evoke the whole social and political system (thus revealing "the cunning of pedagogic reason"). "Bodily hexis - says Bourdieu - is political mythology realized, em-bodied, turned into a permanent disposition, a durable way of standing, speaking, walking, and thereby of feeling and

4 „Et l'on n'en finirait pas d'énumérer les valeurs faites corps, par la transsubstantiation qu'opère la persuasion clandestine d'une pédagogie implicite, capable d'inculquer toute une cosmologie, une éthique, une métaphysique, une politique, à travers des injonctions aussi insignifiantes que 'tiens-toi droit' ou 'ne tiens pas ton couteau de la main gauche' et d'inscrire dans les détails en apparence les plus insignifiantes de la tenue, du maintien ou des manières corporelles et verbales les principes fondamentaux de l'arbitraire culturel, ainsi placés hors de prises de la conscience et de l'explication." 
thinking" (Bourdieu, 1990, p. 69-70). It is no accident that the phrases and expressions concerning bodily postures refer at the same time to states of the soul and to position in social hierarchy - it is well known to everyone who raises her/his head, gets up off her/his knees, falls or bows etc. The body does not represent the past, it enacts it, bringing it back to life. "What is 'learned by body' is not something that one has, like knowledge that can be brandished, but something that one is" (p. 73).

As we mentioned earlier, Maurice Halbwachs did not want to follow his teacher Henri Bergson in analyzing the corporeal aspects of memory, contenting himself with reduction of the memory field to the distinct content of consciousness. He was not, however, in the position to perform consequently this introspective reduction, and his detailed analyses of collective memory lead him into paths later frequented by Pierre Bourdieu. When in the work of Maurice Halbwachs we read about the abilities of a good commander or lawyer, there is no doubt that he writes about the dispositions described many years later with so much detail by Bourdieu. Halbwachs, unlike Pascal, does not treat social automatisms as an expression of human "unreason", but as a synthesis of complex social processes extended over a long period of time. Habits and customs are a kind of practical reason, proved in action in the course of centuries, whose exhaustive explication, if possible at all, would require a great amount of time and effort. As he says, "order, discipline, or military instruction are not enough to conduct a war. Technical qualities cannot replace personal qualities. The general must not only show valor beyond comparison; he must also be capable of sudden inspirations, discoveries, and improvisations based on a knowledge of humanity, the handling of ideas, an active memory, and an ever eager imagination. These qualities can develop only in an environment of intense social life in which the ideas of the past and present join together, and in which contemporary groups and those of yesterday come into contact in some way. The mind becomes sharpened so it can recognize the original traits of each person; the sense of honor and of duty to oneself and family elevates the individual above himself and makes him recipient of the vast resources of the group he represents" (Halbwachs, 1992, p. 130). Similarly the legislator, the councillor and the judge must have a sense of justice, which never is a simple result of studying law. Such necessary insight can only be obtained in the course of many years of experience, exceeding professional situations, in 
contacts with many people, who are used to discern and estimate other people and situations and to pass judgment in various matters.

\section{Incorporating practices - Paul Connerton}

Abilities preconditioning our life in society are subject of analyses performed as well by Paul Connerton. He underlines that we practice and repeat various activities (such as walking, swimming, writing, reading, eating with a knife and fork etc.), until we reach a certain level of competence, enabling us to perform them mechanically. Training is a time in which we allow the past to settle in our bodies in the form of automatisms. We can say that we established a habit, when the degree of conscious awareness and attention necessary for adequate performance of a given activity becomes minimal. Habits are contents of knowledge and memory which already left the mind and settled in the body. As explains Connerton, "many forms of habitual skilled remembering illustrate a keeping of the past in mind that, without ever adverting to its historical origin, nevertheless re-enacts the past in our present conduct. In habitual memory the past is, as it were, sedimented in the body" (Connerton, 2014, p. 72). There are many social practices of embodiment, called by Connerton "incorporating practices." "Thus a smile or a handshake or words spoken in the presence of someone we address, are all messages that a sender or senders impart by means of their own current bodily activity, the transmission occurring only during the time that their bodies are present to sustain that particular activity" (p. 72).

Incorporating practices involve all ways of preserving in memory gestures, attitudes, movements and their sequences characteristic of a given culture. We behave differently in formal (official) and in everyday situations, at home and at work. We are aware of appropriateness or inappropriateness of certain attitudes and behaviors and of their dependence on circumstances. From an early age we learn to behave properly, thanks to vigilance and unending corrections of our educators or by imitation of those who are considered to be fully competent in this matter. "Power and rank are commonly expressed through certain postures relative to others; from the way in which people group themselves and from the disposition of their bodies relative to the bodies of others, we can deduce the degree of authority which each is thought to enjoy or to which they lay claim" (p. 73). 
Choreography of power is expressed by means of the body. Each culture and epoch decides, which attitudes are significant, and which are not. In every epoch and culture, however, certain attitudes are related to certain traits of character, and vice versa. When we say, for instance, that someone stands on her/his feet, we probably do not mean only his or her upright posture, but also independence and good condition; about someone who made a mistake or a slip we say that s/he slipped up. Expressions describing the body are used as metaphors of social attitudes and positions. These metaphors refer to valid, operative and commonly known corporal patterns. Our social existence is deeply embodied - says Connerton. Already ancient authors were aware of it - Quintilian described in detail gestures and movements helping rhetoricians (Quintilian).

In our contemporary world there are places and circumstances (such as church, court, diplomatic relations), in which ways of conduct, repertoire of movements, gestures and words are strictly, or even formally determined. But in our everyday life as well we have to comply with numerous rules, and we usually do it unwittingly. Few people realize that our way of eating is determined by technical abilities, imbued with moral values. ${ }^{5}$ They are forgotten as laws as soon as they are memorized as habits. The principles of etiquette impose inhibition of the reflexes of the body, refine attention, make us sensitive to nuances. They aim at the formation of persons distinguished by proper character, a certain type of sensibility and sense of decency. Society exerts differentiated and detailed control over its members and, as a result, imposes increased individual self-control (social control on its highest level becomes permanent self-control). Meals are one of the occasions to demonstrate who we are, to celebrate artistic refinement, sophisticated styling and ethical virtue. The material reality of eating is veiled, whereas interiorized manners expose sophisticated courtesy and social distinctions. Family dinners are sometimes a real performance, a piece of theater, in which actors play also the role of spectators, regarding others.

5 Rules of behavior at the table valid in the 16. century have been described by Erasmus of Rotterdam (1466/67-1536) in his treaty "On Civilty in Children" or "A Handbook on Good Manners of Children" (De civilitate morum puerilium, Basel 1530); in the same period dissertations concerning mores and customs wrote also Baldassare Castiglione (1478-1529) (Il Cortegiano; Della Casa), and in Poland Lukasz Gornicki, the author of "The Polish Courtier" (Dworzanin polski-1566), adaptation of Castiglione's oeuvre. 
If one side of social practices is the ability to enact complex cultural codes, then its other side is the ability to recognize them. Very few can be proud of their noble glibness and liberty of movement, grace, tact, charming cadence of voice etc., but very few, as well, are in the position to appreciate these abilities and to take delight in them (Proust; this thought is expressed throughout the whole novel). Our manners are forms of our presence in the world, ways of manifesting ourselves in the social space. In every group subject to the strictest assessment are those abilities that are in the least susceptible of yielding to conscious control and pressure of the will, for they are considered to be the utmost expression of true human nature. Someone who is not able to embody the highest ideals of his group is at the same time someone endowed with the right to impose them on others - someone like this passes for (becomes) arbiter of fashion, elegance and good manners. It is the moment in which power, as a result of social alchemy, is transformed into charisma or into the charm suited to evoke affective enchantment, admiration and desire of imitation (Bourdieu, 1990, p. 102). The body possesses in social world the status of a sign that rejects any objection (i. e., symbolic efficiency).

Incorporating practices are the most efficient mnemonic system and withal have the ability to differentiate. It places on the one side those of impeccable manners, and on the other side those who are brutish, coarse, who lack refinement - people of another sort. Both groups are divided by a gap that is almost impossible to bridge. Connerton refers to the example of the nineteenth century petite bourgeoisie, aspiring to belong to the upper crust and thus evoking embarrassment and distaste in elegant society. Every social group reacts with irritation at the sight of someone who combines ambition with incapacity. Those who aspire to social advancement are aware that their body can betray them at any moment, and therefore constantly control and correct themselves, feeling ashamed and embarrassed. They perceive themselves through critical looks of others. They behave like a pupil who took in his clumsy hands a precious instrument and tries to play on it, surveilled by a severe teacher (on difficulties encountered by those who learn to play on musical instruments, see Sudnow). Experience of one's own incapacity is particularly disagreeable and depressing for everyone. The body is in social life the source of uncertainty the bigger, the bigger is the gap between what we desire to be and what we are. We are reminded of existence of this gap by attentive glances of the others, as well as by our own incessant, restless 
self-observation. All that what the body has remembered tells about us more than we think and positions us in social hierarchy, before we manage to say a word.

Incorporating practices, such as rules of conduct at the table or rules of savoir vivre in a broader sense, are thus a salient example, a particularly telling and revealing symbol of the whole sphere of inapparent gestures and ways of behavior, internalized by the body and in the body. It is here that the story of constitution begins and goes on.

\section{Summary: Difficult constitution. Unexplored perspectives}

The word "constitution" in English belongs to kinaesthetic metaphors mentioned above: it means "the action of constituting" (also in philosophical or phenomenological sense), but also "the character of the body as regards health, strength, vitality, etc." (SOED, entry: "Constitution"). Hence the difficult birth of identity (once known as "subject") through body memory, in social force field shaped by habitus we tried to describe, could be pinpointed as difficult constitution, mainly in the first of the above mentioned meanings, with a strong reference to the second. The difficulty in question is testified by the last accord of our analysis - the story of arrivists trying to belong to society, but too clumsy to perform all the necessary exercises.

This difficulty has accompanied our considerations all along the way - internalized coercion described by Norbert Elias made room for a certain field of autonomy, related to agency, liberty and flexibility of individuals, assimilating patterns of behavior that are no rigid schemes, but rules changing in a Wittgensteinian world of liquid games. Liquidity of social coercion games creates space, in which the Foucaultian body reveals itself as an agent memorizing the past, a complex medium of memory. Memory analysis shows the complex, subtle and flexible nature of the identitarian passage from the procedural, structural and intercorporeal to the incorporative type of memory, in which the body turns out to be the quasi-subjective social agent re-staging the living past in the present, preceding and primary to conscious representation of "bygone times." Paradoxical nature of this quasi-subjective agency becomes apparent in constant presence of the painful and traumatic side of body training and coercion - the body with its capacities to memorize and assimilate the past, enabling it to interact adequately with the world, is 
always the Foucaultian body, subject to coercion and trauma, characterized by inadequacy of reactions in the traumatic mode of memory. An important aspect of this autonomous-traumatic agency of the body is its capacity to reorient and project the living past into the future. This particular trait opens interesting possibilities of interpretation: the body, enacting the living past and projecting it into the future, endowed with entire retentional-protentional dynamics of the phenomenological subject, can be further described in terms of a reinterpretation of the Husserlian analysis of time, as we know it from Husserl's On the Phenomenology of the Consciousness of Internal Time (Husserl, 1991). Fundamental intuitions leading towards a phenomenology of perception, focusing on space and the world as they are perceived by the body, have been presented in the seminal work of Maurice MerleauPonty (Merleau-Ponty, 2001) and developed further by many authors, e.g. in the neopragmatic vein in Richard Schusterman's project of somaesthetics (Schusterman, 2012).

What we have seen in the analysis of typology of body memory, confirms itself in Bourdieu's reflection on human agency in social force field. Habitus, being the cause and result of social coercion, is simultaneously a way of carrying responsibility in the world - a throughout subjective function. Habitus is the source of social order, evidence and assent - fundamental features of human cognitive acts. Stating that cognitive structures are not forms of consciousness, but dispositions of the body, Bourdieu goes very far, explicitly reinterpreting the whole neo-Kantian and phenomenological tradition of understanding transcendentality - certainly in the Durkheimian vein, but intending to go beyond Durkheim, as he himself admits (Bourdieu, 1998 , pp. 54-55 $)$. This intuition, too, opens new perspectives of interpretation of important philosophical themes, but - just like the above mentioned reinterpretation of the retentional-protentional structure of time - remains an unexplored land, requiring new analyses and vocabulary.

The key to these new perspectives seems to lie in the description of grim, painful coercive practices of training the body and instilling in it social habitus, common in a way to all authors analyzed above. Their

${ }^{6}$,It is necessary to break with the intellectualism of the neo-Kantian tradition to acknowledge that cognitive structures are not forms of consciousness but dispositions of the body [...]; we need to go beyond the neo-Kantian tradition, even in its Durkheimian form, on yet another count." 
considerations, as we have seen, are hardly susceptible to recapitulation. Therefore I leave them as they are, hoping that they can encourage further reflection.

\section{Bibliography}

Assmann, A. (1999). Erinnerungsräume: Formen und Wandlungen des kulturellen Gedächtnisses. München: C.H. Beck.

Bachelard, G. (2002). The Formation of the Scientific Mind. Trans. M. McAllester Jones. Manchester: Clinamen Press.

Bourdieu, P. (1980). Le sens pratique. Paris: Les Editions du Minuit.

Bourdieu, P. (1998). Practical Reason. On the Theory of Action. Stanford: Stanford University Press.

Bourdieu, P. (1990). The Logic of Practice. Trans. R. Nice. Cambridge: Polity Press.

Bourdieu, P., Loic, J.D. (1992). An Invitation to Reflexive Sociology. Chicago: The University of Chicago Press.

Casey, E.S. (2000). Remembering. A Philosophical Study. Bloomington: Indiana University Press.

Castiglione, B. (2019). The Book of the Courtier (Il Cortegiano) [1528]. Trans. L.E. Opdycke.. New Delhi: Gyan Publishing House.

Connerton, P. (2014). How Societies Remember. Cambridge: Cambridge University Press.

Dennett, D. (1991. Consciousness explained. Boston: Little, 1991.

Elias, N. (1939). Über den Prozeß der Zivilisation. Basel: Verlag Haus zum Falken.

Elias, N. (1969). The Civilizing Process. Trans. E. Jephcott. Oxford: Blackwell.

Elias, N. (2010). The Society of Individuals. Trans. E. Jephcott. Dublin: UCD Press.

Erasmus of Rotterdam (2008). A Handbook on Good Manners for Children (De civilitate morum puerilium) [1530]. Trans. E. Merchant. London: Preface Publishing.

Foucault, M. (1984). "Nietzsche, Genealogy, History." Trans. D.F. Bouchard, Sh. Simon. In: P. Rabinow (ed.), The Foucault Reader (pp. 76-100). New York: Pantheon Books.

Foucault, M. (1990). The History of Sexuality. Vol. 1: The Will to Knowledge. Trans. R. Hurley. London: Penguin Books, 1990. 
Foucault, M. (1995). Discipline and Punish: The Birth of the Prison. Trans. A. Sheridan. New York: Vintage Books, 1995.

Foucault, M. (1997). "Il faut défendre la société." Cours au Collège de France, 1975-1976. Paris: Le Seuil.

Górnicki, Ł. (1954). Dworzanin polski [The Polish Courtier, 1566]. Ed. R. Pollak. Wrocław: Zakład im. Ossolinskich.

Gallagher, S., Zahavi, D.. The Phenomenological Mind. An Introduction to Philosophy of Mind and Cognitive Science. London: Routledge.

Halbwachs, M. (1925). Les cadres sociaux de la mémoire. Paris: Félix Alcan.

Halbwachs, M. (1992). On Collective Memory. Trans. L.A. Coser. Chicago: The University of Chicago Press.

Husserl, E. (1991). On the Phenomenology of the Consciousness of Internal Time. Trans. J.B. Brough. Dordrecht: Kluwer.

Husserl, E. (1998). Ideas Pertaining to a Pure Phenomenology and to a Phenomenological Philosophy. Trans. F. Kersten. Dordrecht: Kluwer.

Lemke, Th. (2011). Biopolitics: An Advanced Introduction. New York: New York University Press.

Mauss, M. (1950). Sociologie et anthropologie. Paris: Presses universitaires de France.

Merleau-Ponty, M. (2001). Phénoménologie de la perception. Paris: Gallimard.

Miłkowski, M. (2003). "Heterofenomenologia i introspekcja.” Przegląd FilozoficznoLiteracki, 4 (6), 111-129.

Nietzsche, F. (1989). On the Genealogy of Morals. Trans. W. Kaufmann, R.J. Hollingdale. New York: Vintage Books.

Pascal, B. (1901). The Thoughts of Blaise Pascal. Trans. C. Kegan Paul. London: George Bell and Sons.

Pokropski, M. (2013). Cielesna geneza czasu i przestrzeni. Warszawa: Wydawnictwo IFiS PAN.

Proust, M. (2004). In the Shadow of Young Girls in Flower. Trans. J. Grieve. New York: Viking.

Quintilian (2006). Institutio Oratoria. Oxford: Oxford University Press.

Schusterman, R. (2012). Thinking through the Body. Essays in Somaesthetics. Cambridge: Cambridge University Press. 
Sloterdijk, P. (2013). "The Conquest of the Improbable. For an Acrobatic Ethics. Programme.” In: Idem. You Must Change Your Life. Trans. W. Hoban (pp. 109-110). Malden: Polity Press.

Sudnow, D. (2002). Ways of the Hand: The Organization of Improvised Conduct. Cambridge, MA: MIT Press.

The Shorter Oxford English Dictionary (SOED) (2002). 5th edition. Oxford: Oxford University Press.

Żardecka, M. (2020). Pamięć i zapomnienie. Filozoficzny dyskurs o sile i stabości pamięci indywidualnej i zbiorowej. Rzeszów: Wydawnictwo Uniwersytetu Rzeszowskiego.

\begin{abstract}
Body memory is a relatively new philosophical notion, entangled in interiorization of the past - paradoxically this entanglement liberates the individual from the dictature of the present flow and enables her/his autonomy. The author intends to show that this apparent ensnarement, with all its difficult genesis, makes us responsible, active agents, influencing our environment. To achieve this objective, she chooses to describe the painful and ambiguous process of training and drilling the body, immersing us in social patterns, and thus in the living past. This path leads us a paradox again - to the arduous and painstaking rediscovery of the issue of subject. There is still hope that we can recuperate this vanishing notion, reinterpreting the most essential classical themes of philosophy, such as time and transcendentality. But the subject matter remains opaque, and requires further reflection.
\end{abstract}

\title{
Cytowanie
}

Magdalena, Ż. (2021). Difficult Birth of the Agent. Memory of the Body, Identity and Social Competence. Analiza i Egzystencja, 56 (4), 5-23. DOI: 10.18276/ aie.2021.56-01. 